\title{
PARÁdi József Karhatalom a polgári magyar állam rendvédelmében 1867-1945
}

A karhatalom közigazgatási szervezetek részéről történő igénybevétele valószínűleg az állam létével egyidős. Az a neoliberális dogma, mely szerint a haderőt a rend védelme érdekében nem szabad igénybe venni új keletú, csupán a rendszerváltás nyomán került felszínre Magyarországon. E jól hangzó dogmának azonban nem sok értelme van, hiszen a haderő és a rendvédelmi testületek ugyanazon kormány kompetenciába tartoznak. Felkészítés és felszerelés, valamint jogi szabályozás kérdése csupán, hogy a haderő vagy a rendvédelmi testületek kijelölt alakulatait teszik képessé egy-egy országban a karhatalmi teendők ellátására. Az azonban biztos, hogy a rendvédelmi szervezetekben kialakított karhatalmi alakulatok többletköltséget igényelnek, mert erre a célra külön csapatokat kell létrehozni. A haderőben viszont a meglévő csapatok közül lehet kijelölni, felkészíteni és felszerelni karhatalmi feladatok ellátására alakulatokat.

A vizsgált időszakban mindenki számára ugyanolyan evidencia volt, hogy a haderő az ország védelmét szolgálja mint az, hogy a haderőt a közhatóságok a közrend és a közbiztonság fenntartása érdekében végső esetben karhatalmi teendők ellátására igénybe vehetik. Sem Magyarországon sem pedig másutt nem tartották összeegyeztethetetlennek a haderő csapatainak karhatalmi igénybevételét a demokrácia, vagy éppen az alkotmányos monarchia szabályaival. Inkább arra fordítottak gondot, hogy a haderő karhatalmi igénybevételét megfelelö módon szabályozzák.

Hazánkban a karhatalmi teendőkből a haderő kivonására a rendszerváltás nyomán került sor. Akkor a fö érv az volt, hogy a haderő karhatalmi feladatköre pártállami csökevény, amely összeegyeztethetetlen a polgári demokráciával. Ez azonban nyilvánvalóan hazug érv, hiszen a polgári magyar állam időszakában bevett gyakorlat volt a haderő csapatainak karhatalmi célú igénybevétele, ezáltal pedig egyáltalán nem ingott meg a polgári magyar állam. A magyar pártállam csupán alkalmazta a polgári magyar állam müködése során kialakult gyakorlatot. A magyar demokrácia számára átvehetetlen gyakorlatot tehát nem a haderő csapatainak karhatalmi alkalmazása jelentette, hanem a nem kellő szabályozottság.

Már a vizsgált időszak kezdetén gróf ANDRÁSSY Gyula ${ }^{1}$ azzal érvelt a honvédség felállítása mellett, hogy a Magyar Királyságban a belső rend fenntartása érdekében feltétlenül szükség van katonai erőre, amely a közös hadsereg nem lehet. Abban az esetben tehát, ha a honvédség felállítására nem kerül sor, a tényleges hadsereg kettéosztásával kell a magyar hadsereget létrehozni. ${ }^{2}$ Erre jogalapot a kiegyezési törvényben foglaltak szolgáltattak, nevezetesen „Az egész hadsereg és így a magyar hadsereg is, mint az összes hadsereg kiegészítő része". ${ }^{3} \mathrm{Az}$ uralkodó azonban nem kívánta megosztani a haderőt, egyben ragaszkodott a haderő feletti vezérleti, vezényleti és belszervezeti jogköréhez. ${ }^{4} \mathrm{~A}$ helyzetet végül is a haderő átszervezése oldotta meg. A haderő átszervezésére alapvetően azért került sor, mert át kellett térni az általános hadkötelezettségre. ${ }^{5}$ Az 1868 végén elfogadott törvények szerint ${ }^{6}$ a „fegyveres erö” a „hadsereg”-ből (közös hadsereg), a „haditengerészet”-ből, a „honvédség”-ből és a „népfölkelés”-ből állt, Ausztriában pedig a honvédségnek a „Landwehr” a népfelkelésnek a „Landstrum” felelt meg. ${ }^{7}$

A haderőről szóló kiegyezés körüli viták nem a haderő karhatalmi alkalmazásáról szóltak, azzal mindenki egyetértett. Az ördög azonban a részletekben rejtőzik, így a haderő csapatainak karhatalmi alkalmazása során kerültek felszínre azok a témák, melyeket rendezni kellett.

Eleink a vizsgált időszak kezdetén karhatalomnak tekintettek minden tevékenységet, amelyet fizikai kényszerítéssel, vagy annak közvetlen kilátásba helyezésével valósítottak meg a közigazgatás szervezetinek a nevében. A polgári magyar rendvédelem kialakításának az időszakában, a kiegyezést követően azonban nem mindig állt kellően felkészített és felszerelt föképpen pedig kellő létszámú rendvédelmi erő a közigazgatási hatóságok rendelkezésére. Talán még ennél is fontosabb volt azonban, hogy a legkellemetlenebb feladatok, mint például a váltótörvényszéki végrehajtások, illetve az úrbéri peres ügyek végrehajtásai esetében a kényszerítő erőt - azaz a korabeli értelmezés szerinti karhatalmat - erőszeretettel igényelték a haderőtől. A karhatalom témakörében született első rendelet arról szólt, hogy karhatalmi segédletet akkor lehet kérni, illetve kapni a haderőtől ha a 
közbiztonság veszélyben forgott. Magánjogi esetből származó bírói döntések kikényszerítése esetében nem a haderőt, hanem a rendvédelmi testületeket kellett igénybe venni. ${ }^{8}$

Melyek voltak ezek a rendvédelmi erők, amelyeket a közigazgatás karhatalmi teendők ellátása érdekében igénybe vehetett? Miből állt a kiegyezés nyomán kialakuló rendvédelmi struktúra? E kérdések megválaszolása két okból lehet érdekes. Egyrészt a korabeli magyar rendvédelmi modell testületeinek jellege magát a karhatalmi felhasználhatóságot is meghatározta. Másrészt pedig a polgári magyar állam rendvédelmi modelljének a rögzítése azért is fontos mivel — néhány módosítástól eltekintve — lényegében ma is ez a struktúra müködik.

A polgári magyar állam rendvédelmi modellje két fő pilléren, a csendőrség és a rendőrség típusú rendvédelmi testületeken nyugodott. Ebből fakadóan a Magyar Királyság az úgynevezett kontinentális rendvédelmi modellbe tartozott, ellentétben az angolszász modellel, amely nem ismerte a csendőrség intézményét. A csendőr és a rendőr szavaink egyaránt a nyelvújítás eredményei. 1840-ben jelent meg először a rendőr szó törvényeinkben a mezei rendőrségről szóló jogszabályban, a csendőr kifejezés pedig az államköltségvetésről szóló 1873. évi törvényünkben fordult elő először. Korábban a csendőrséget - a francia gendarmerie kifejzés nyomán — zsandárság szóval illették. ${ }^{9}$

Eredetileg a municipálisok és a centralisták a reformkori közigazgatás fejlesztési vitájában a rendőrségeken nyugvó rendvédelmi modell aratott győzelmet. A kiegyezés nyomán ennek a bevezetésére került sor. Ez a rendörségcentrikus modell azonban az 1870-es években látványosan megbukott, mivel egyedül a törvényhatósági jogú városok rendelkeztek olyan összegü bevétellel, amely lehetővé tette hatékony rendőrség létrehozását és müködtetését. Mivel azonban a közrend és közbiztonság — vagy ahogyan a kortársak nevezték a közbátorság - a polgári fejlődés nem elhanyagolható feltétele volt, ezért a megbukott rendvédelmi modellt, más hatékonyabb modellel kellett felcserélni. Így került elötérbe a csendőrség intézménye. A csendőrség mint rendvédelmi szervezettípus Európa legrégebbi rendvédelmi szervezetei közé tartozik. A francia kutatók a szervezetet a XIII. századig vezetik vissza. Ekkor még Maréchaussée névre hallgatott és a haderőn belüli rendfenntartó szervezet volt. Fokozatosan terjedt ki a hatásköre a polgári lakosságra, a hadmüveleti területeken túlra, az ország egész területére béke időszakban is. XVI. Lajos uralkodása idején kapta a testület a gendarmerie elnevezést. A testületet ugyan a francia polgári forradalom megszüntette, azonban hamar kiderült, hogy szükség van rá, ezért reorganizálták a szervezetet, ${ }^{10}$ Bonaparte NAPÓLEON pedig modernizálta a csendőrséget. A napóleoni császárság vonzáskörébe kerülő államokba exportált francia közigazgatási modell részeként került bevezetésre a csendőrség Európa számos országában. Bonaparte NAPÓLEON bukását követően azonban a csendőrséget nem oszlatták fel, hanem azon európai országokban is bevezették, ahol korábban ilyen szervezet még nem volt. ${ }^{11}$ A XIX. században — a Brit-szigetek kivételével — Európa valamennyi országában müködött csendőrség, még a Török-birodalomban is. A csendörség azért vált népszerüvé, mert gyorsan, olcsón és tartósan volt képes rendet teremteni, illetve a rendet fenntartani ott, ahol a rendőrségek jóval nagyobb költséggel sem tudtak rendet létrehozni és fenntartani.

A Magyar Királyi Csendőrség létrehozása a harmadik kezdeményezés volt a csendőrség típusú rendvédelmi szervezet létrehozására Magyarországon. Már a reformkorban kísérletet tettek a förendek a magyarországi csendőrség létesítésére. Gyüjtést is szerveztek a magyar csendőrség létrehozására. Kezdeményezésük azonban az uralkodó rokonszenvét nem nyerte el, így a csendőrség ügye elhalt. ${ }^{12}$ A csendőrség intézménye Lombardián keresztül került be a HABSBURG-birodalomba. Lombardia ugyanis - amely hagyományosan HABSBURG tartomány volt - a napóleoni császárság vazallus államává vált, így ott is bevezették a csendőrséget. Miután azonban a tartomány visszakerült a HABSBURG-birodalomhoz, az eredményesen tevékenykedő szervezetet nem szüntették meg, hanem tovább müködtették. ${ }^{13}$ A magyar forradalom és szabadságharc cári segédlettel megvalósított leverése után pedig a neoabszolutista birodalmi vezetés felismerte a csendörség típusú rendvédelmi szervezetben rejlö lehetőséget, ezért — a lombardiai csendőrség mintájára — létrehozta a HABSBURG birodalmi csendőrséget. ${ }^{14}$

Ez azonban — bár a Kárpát-medencében is müködött — nem volt magyar csendőrség, hanem a HABSBURG-birodalom csendörsége volt. A kiegyezéssel — mint a magyarság 
elnyomásában jeleskedő szervezetet — a birodalmi csendőrség magyarországi alakulatait a magyar kormány nem vette át. Az Osztrák Császárságban azonban a csendőrség tovább müködött. A Magyar Királyságban a csendőrség intézménye egyedül Erdélyben és Horvátországban maradt fenn 1867 után is, mint a közös haderő alakulata. Ez a helyzet azonban ellentétes volt a kiegyezési törvényben foglaltakkal, mivel a rend fenntartása nem tartozott a közös ügyek közé. Végül is a magyar kormány — az ellenzék kitartó támadásait követően - a két csendőr ezredet átvette a közös hadseregtől 1876-ban. Az erdélyi csendőr ezred vált a Magyar Királyi Csendőrség kiindulási alapjává. ${ }^{15}$

A Magyar Királyi Csendörséget 1881-ben törvényi úton hozták létre. ${ }^{16}$ A testület a Magyar Királyi Belügyminisztérium által — amely a szervezet irányítását látta el — a központi államhatalom felügyelete alatt állt. Katonailag szervezett örtestület volt, azaz a személyi állomány tagjai katonai rangot viseltek, az alá- fölérendeltségi viszonyok katonaiak voltak, a testületi tagok a honvédelmi tárca kompetenciájába tartoztak, mivel személyükben katonának minősültek, őket a katonákra vonatkozó általános jogok illették meg, illetve kötelezettségek terhelték. A testület hatásköre - a városok kivételével - a teljes Magyar Királyság területére kiterjedt. A horvát csendőrség is a Magyar Királyi Csendőrség részét alkotta, bár abban autonóm módon müködött. Az Osztrák-Magyar Monarchiában — a horvát csendőrséget nem számítva önálló csendőrségnek — három csendőrség müködött, az Osztrák Császárság csendőrsége, a Magyar Királyság csendőrsége és Bosznia-Hercegovina csendőrsége. ${ }^{17}$

A Magyar Királyi Csendőrség létszáma 12000 fő volt a dualizmus időszakában és a trianoni békediktátum által megcsonkított Magyar Királyságban is. A terület-visszacsatolások nyomán a szervezet létszámát 22000 före növelték. A megalakulás és az I. világháború éveit leszámítva 90 \% körüli bünfelderítési mutatóval müködött a testület. Ehhez hasonló kiváló eredményt azóta sem tudott egyetlen magyar rendvédelmi szervezet sem létrehozni. ${ }^{18}$ A dualizmus időszakában az egyetlen magyar testület volt, amely a személyi állomány felkészítettségéből és felszereltségéből valamint a testület vezetésének a jellegéből fakadóan alkalmas volt csapaterős karhatalmi feladatok ellátására. A Magyar Királyi Csendőrséget azonban elsősorban kisebb létszámot igénylő karhatalmi teendők teljesítésére vették igénybe, mivel a testület személyi állománya kis létszámú örsökön és nagy területen szétszórva diszlokált. Ebből fakadóan pedig nehézséget okozott a nagyobb létszám összevonása. ${ }^{19} \mathrm{Az}$ I. világháború után a Duna-Tisza közén hoztak létre vezénylés útján zászlóalj erejű csendőrségi öszszpontosítást. A gyanútlan csendőröket azonban az éj leple alatt a Tanácsköztársaság terror alakulatai meglepték, lefegyverezték, a személyi állományt pedig hazaküldték.

Karhatalmi célzattal a Magyar Királyi Csendőrségen belül erőkoncentrációt a II. világháború időszakában hoztak létre. Ekkor — a II. világháború ezirányú tapasztalatait használva - hozták létre a galántai csendőr zászlóaljat, elsősorban a diverziós tevékenység felszámolása érdekében. A zászlóalj személyi állománya —a tisztek és az altisztek kivételével — sorozott állományból álltt. ${ }^{20}$

A Magyar Királyi Csendőrség fennállása során több szolgálati szabályzat követte egymást. ${ }^{21}$ A legutolsó csendőrségi szolgálati szabályzatot Magyarországon 1941-ben adták ki „Szervezeti és szolgálati utasitás a Magyar Királyi Csendörség számára” címmel. ${ }^{22}$

A Magyar Királyi Állami Rendőrség ${ }^{23}$, majd - az 1931. évi átszervezés nyomán — a Magyar Királyi Rendőrség ${ }^{24}$ volt a magyar rendvédelem második pillér szervezete. Ez a helyzet azonban csak a magyarországi rendőrségek 1919-1921 között megvalósult államosítása nyomán jött létre. Addig a magyar rendőrségek lényegében alkalmatlanok voltak csapaterős karhatalmi feladatok ellátására, bár a fővárosi rendőrség és néhány nagyobb vidéki városi rendőrség rendelkezett olyan létszámmal, amely már lehetővé tehette volna karhatalmi alakulat kiállítását. Az állami rendőrségek — azaz a fővárosi rendőrség ${ }^{25}$, a határrendőrség ${ }^{26}$ és a fiumei rendőrség ${ }^{27}$ - kivételével azonban a városi rendőrségek személyi állományának a fegyverzete tarka volt, mivel a rendörök fegyverüket önállóan szerezték be. A fegyverzet egységesítettségéhez hasonló helyzet a magyarországi rendőrségeknél akkor állt elö, amikor a Magyar Királyi Csendőrségnél a forgópisztolyokat Frommer-féle öntöltő marokfegyverekre cserélték. A forgópisztolyokat pedig - amelyek használható, jó állapotban voltak — kedvezményes áron felajánlották a rendőrségek személyi állománya számára, akik éltek is a kedvező beszerzés 
lehetőségével. ${ }^{28} \mathrm{~A}$ rendőrségek tagjaira nem volt jellemző a karabély birtoklása. A rendőri örszemélyzet felkészültsége is meglehetősen tarka volt. Általában a városi rendőrségeket fenntartó városi elöljáróságok a rendőrségeik személyi állományának 1/5-ében határozták meg az analfabéták arányát. A rendőri őrszemélyzetek tekintetében nem volt egységes képzést biztosító tanfolyam mint a csendőrségnél. A rendőri őrszemélyzetek új tagjait idősebb járőrvezetővel osztották be szolgálatra. A bevonulást követően pedig — a mentori feladatkörre felkért, magasabb rangú és tapasztalt — testületi tag beszámoltatta az új rendőrt megmagyarázva, hogy mi a helyes és a helytelen eljárás. Ezt a beszámoltatást és annak értékelését addig folytatták, amíg az új rendőr kellő ismeretekre, illetve gyakorlatra szert tett. Ilyen felkészítettségü és fegyverzetủ személyi állománnyal csapaterős karhatalmi feladatokat nem lehetett ellátni. A magyarországi rendőrségek csapaterős karhatalmi igénybevételét az is nehezítette, hogy az önkormányzati rendőrségek kompetenciája a város határáig terjedt.

Alapvetően változott meg a helyzet a rendőrségek államosításával. Ezzel létrejött a rendőrségen belül az egész országra kiterjedő egységes szakmai felkészítettség, egyenruházat, felszerelés és fegyverzet, valamint az államosított rendőrség hatásköre már kiterjedt valamennyi törvényhatósági jogú és rendezett tanácsú város területére. Az államosított rendőrség azonban polgári fegyveres őrtestület maradt, mivel a személyi állomány belső függelmi viszonyai a hivatalnoki kar szabályozásai szerint müködtek. A rendőrök rendőri rangot viseltek, személyükben nem minősültek katonának, így nem is tartozhattak a honvédelmi tárca kompetenciájába, a katonákra vonatkozó általános kötelezettségek, illetve jogosultságok a rendöröket nem terhelték, illetve nem illették meg. ${ }^{29}$ A testület karhatalmi feladatok ellátását biztosító képességei gyarapodtak ugyan, azonban külön a karhatalmi teendők végzésére specializált szervezeti egységet csak a fővárosban hoztak létre. A fövárosi rendőrség karhatalmi alakulatát. A Mosonyi utcai laktanyába telepítették. Ez az alakulat a rendőrségek államosításakor jött létre, a személyi állományának a legénységi részét kezdetben naponta vezényelték a kerületi kapitányságoktól. 1932. I. 8-án hozták létre - a magyarországi rendőrségek történetében első ízben - állandó személyi állománnyal rendelkező karhatalmi alakulatként a karhatalmi századot. A karhatalmi századot továbbfejlesztették, így jött létre a karhatalmi zászlóalj 1934. IV. 16-án. A dualizmuskori rendőrségek és a két világháború közötti Magyar Királyság rendőrségének a létszáma is mintegy 12000 fő volt — a Magyar Királyi Csendőrség létszámához hasonlóan — a terület-visszacsatolások után pedig a rendőrségi létszám is 22000 före nőtt. ${ }^{30}$

A Magyar Királyi Pénzügyőrség (1867-1945) a magyar rendvédelmi testületek részét képezte, amely a karhatalmi teendők ellátásában nem kapott szerepet, bár az egységes képzése ruházata, felszereltsége és fegyverzete — amely a legénység esetében a karabélyt is magába foglalta - és irányítása, valamint az ország teljes területére kiterjedő hatásköre biztosított volt. A testület tagjait azonban nem készítették fel csapaterős karhatalmi teendők ellátására, ilyen jellegü hatáskörrel a szervezetet nem ruházták fel és a csekély létszámú mintegy 3000 fös testület személyi állománya — apró szervezeti egységekre bontva — szétszórtan helyezkedett el az országban. ${ }^{31}$

A büntetés-végrehajtási szervezet (1867-1945) személyi állománya a büntetésvégrehajtási intézetekhez tapadt. Szakirányú felkészítetlenségük, felszereltségük jellege, a testület jogosultságainak szabályozottsága, a büntetés-végrehajtási intézetekhez szorosan kapcsolódó alkalmazásuk miatt a testület személyi állománya csapaterős karhatalmi feladatok ellátására alkalmatlan volt. ${ }^{32}$

A Magyar Királyi Koronaőrség (1867-1945), a Magyar Királyi Képviselőházi Örség (1912-1945) és a testőrségek azaz a dualizmuskori Magyar Királyi Nemesi Testőrség és az 1904ben felállított Magyar Királyi Darabonttestőrség, majd a két magyar testőrség maradványaiból létrehozott Magyar Királyi Testőrség (1920-1945) csapaterős karhatalmi feladatok ellátásába való bevonásának a gondolata fel sem merült. Valamennyi testület személyi állományának a létszáma - az 1940-es évek testőrségét leszámítva - 100 fö alatti volt. ${ }^{33}$

A két világháború közötti időszakban a magyar rendvédelmi modell gyarapodott $\underline{a}$ Magyar Királyi Vámörség (1921-1932) ${ }^{34}$ és utódszervezete a Magyar Királyi Határörség (1932-1938) $^{35}$, valamint a Magyar Királyi Folyamörség (1921-1939) ${ }^{\mathbf{3 6}}$ testületeivel. Ezen testületeknek azonban - a legális rendvédelmi feladatkörük mellett, amely lényegében a 
rejtett feladataik fedését szolgálta — a fó feladatuk a trianoni békediktátum káros hatásainak az enyhítése alkotta, azaz a katonai erő rejtése képezte. ${ }^{37}$ Ebből fakadóan nem volt célszerű e testületekre csapaterős karhatalmi teendők ellátását bízni, különösen nem 1928-ig az ANTANT Szövetségközi Ellenőrző Bizottsága magyarországi müködéséig. A fegyverkezési egyenjogúság visszanyerése után létrehozott 1939. évi honvédelmi törvény ${ }^{38}$ következtében a Magyar Királyi Honvédségbe Magyar Királyi Honvéd Folyamerők és Magyar Királyi Honvéd Határvadászok elnevezéssel, csapatnemként visszaintegrált folyamőrségre és határörségre pedig a Magyar Királyi Honvédségre vonatkozó karhatalmi szabályozás volt érvényben.

A polgári magyar állam rendvédelmi testületei közül tehát nem mindegyik szervezet volt alkalmas csapaterős karhatalmi teendők ellátására. A karhatalom fogalmának tartalma is formálódott a polgári magyar állam időszakában. Ezen változások nyomán alakult — az igényekből, azok teljesíthetőségéből és a költségekből fakadóan - a tevékenység szabályozása. Mint minden tevékenységnek a karhatalmi teendőknek is voltak azonban gyenge pontjai.

A karhatalom igénybevétele neuralgikus részének bizonyult a költségtérítés. A kiegyezési törvényben foglaltak szerint ugyanis az Osztrák-Magyar Monarchia két társországa az Osztrák Császárság és a Magyar Királyság fedezte — a mindenkori kvóta arányában — a haderő költségeit. A kvóta a két társország gazdaságának az egymáshoz viszonyított arányát jelölte. A haderő nem rendelkezett kompetenciával a polgári közigazgatás terrénumában. A kiképzést és a harckészültséget pedig nyilvánvalóan zavarták a közigazgatás karhatalmi erők igénybevételére irányuló nem ritka kéréseinek a teljesítései. Ezért teljes joggal igyekezett az állam müködését veszélyeztető esetekre redukálni a karhatalmi kirendeléseket a véderő vezetése. Ezzel szemben pedig a Magyar Királyság közigazgatása és a bíróságok nehezen értelmezték azt a helyzetet, hogy a magyar állam költségvetéséböl is fenntartott haderőt miért nem lehet karhatalmi feladatok teljesítésére is igénybe venni, hiszen a haderő személyi állománya felkészítettsége és felszereltsége tekintetében karhatalmi teendők ellátására alkalmas volt. Ebben a helyzetben törvényszerü volt, hogy a magyar állam rendeletben szabályozta a karhatalmi költségek térítését. E szerint a magyar állam részéről a haderőtől igényelt karhatalmi tevékenység költségeit az igazságügyi tárca elölegezte meg, végső soron azonban arra az állami hatóságra, vagy magánszférába tartozó szervezetre kívánták hárítani a költségeket, amelyek miatt a karhatalom igénybevétele szükségessé vált. ${ }^{39}$

Nyilvánvalóvá vált, hogy különbséget kell tenni a nagyobb létszámú karhatalmi erő a korabeli értelmezés szerint két-három járás pandúrjainak a létszámát meghaladó élőerő bevetésének - alkalmazása és a kisebb létszámú élőeroot igénylő karhatalmi feladat ellátása között. A csekély létszámú erőt igénylő karhatalmi teendőket „rendőri segélynek” nevezték. Rendőri segélyt pedig nem lehetett a haderőtől kérni. A közigazgatás és a bíróságok rendőri segélyért a magyarországi rendőrségekhez fordulhattak. Amennyiben pedig a rendöri segély mérvét meghaladó karhatalom alkalmazására mégis szükség volt, annak igényét az alispánon keresztül lehetett a haderőhöz eljuttatni. ${ }^{40} \mathrm{~A}$ kirendelt karhatalom költségtérítése tekintetében pedig a honvédelmi miniszter közrendeletben határozta meg a kirendelt karhatalom elszámolható napi költségét / fö összegben. ${ }^{41}$

A karhatalom alkalmazására először magyar nyelvü átfogó szabályozás 1876-ban jelent meg. ${ }^{42}$ Ezt követően mintegy tízévente újraszabályozták a témát. Az újraszabályozások alkalmával alapvetően nem változtattak a kialakult gyakorlaton, hanem a keletkezett tapasztalatokkal gazdagították a szabályozást. ${ }^{43}$ A témakör átfogó újraszabályozására 1918-ban került sor. E szabályozás elsősorban azért jött létre, hogy az őszirózsás forradalom nyomán módosult közhatalmi intézmények és rendvédelmi testületek helye és szerepe egyértelmüvé váljék a karhatalom igénybevétele területén. ${ }^{44} \mathrm{~A}$ magyarországi Tanácsköztársaság után a témakört elöször 1924-ben szabályozták átfogó módon, amely már tartalmazta a háború és a forradalmak tapasztalatait is. ${ }^{45} \mathrm{Ez}$ a szabályozás jóval részletesebb volt a dualizmuskoriaknál, azonban két év sem telt el máris kiadásra került az új szabályozás. ${ }^{46}$ Ez azonban tartósnak bizonyult, mivel újraszabályozásra legközelebb 1942-ben került sor, amely nyilvánvalóan tartalmazta a II. világháború során 1942-ig keletkezett 
tapasztalatokat is. ${ }^{47}$ Ez a szabályozás egyben a vizsgált időszakban a téma legrészletesebb és legsokoldalúbb szabályozása volt.

Összességében a polgári magyar állam időszakában — a korábbi gyakorlatnak megfelelően - csapaterős karhatalmi tevékenységet alapvetően a haderő alakulatai láttak el. Igénybevételük szabályozása — a keletkezett tapasztalatok nyomán — folyamatosan vált egyre részletesebbé. A szabályozások lényege - az alkalmazás hatékonyságának biztosítása mellett - a jogszerüség fenntartása volt. A polgári magyar állam időszakában fel sem merült annak a gondolata, hogy a véderő által teljesített csapaterős karhatalmi teendők az alkotmányos monarchia szellemiségével ellentétesek lettek volna. Nem is lehetett volna e tevékenységet a véderő kizárásával hatékonyan ellátni, hiszen a korabeli magyar rendvédelmi testületek egy része a karhatalmi teendö végzésére alkalmatlan volt. A karhatalmi feladatok ellátására alkalmas magyar rendvédelmi szervezetek is - a rendőri segély típusú teendők végzése mellett — elsősorban a kisebb létszámú csapaterős karhatalmi feladatok teljesítésére voltak képesek.

A karhatalom fogalma is változáson esett át, mivel kezdetben minden a rend fenntartása érdekében kifejtett tevékenységet karhatalomnak neveztek, ahol a fizikai kényszerítés vagy annak közvetlen lehetősége létrejött. Ebből fejlődött ki a rendőri segély és karhatalom különválása, majd a rendvédelmi testületek — döntően a Magyar Királyi Csendőrség — által megvalósított karhatalmi teendők és a haderő csapatai által végrehajtott karhatalmi cselekmények megkülönböztetése. A közbeszédben, a zsurnalisztikában azonban továbbra is fennmaradt a karhatalom gyüjtö fogalomként való használata, amelybe tartozónak tekintették a rendőri segélyt és a karhatalmi teendöket egyaránt.

A polgári magyar állam rendvédelmi modelljében nem alakult ki a karhatalmi teendők ellátására specializált szervezet. Ez alól kivételt a főváros jelentett, ahol a vizsgált 83 éves időszak utolsó 10 évében müködött karhatalmi zászlóalj, illetve a II. világháború időszaka, amikor a Magyar Királyi Csendőrség kötelékében — a világháborús tapasztalatok nyomán sorozott állományú csendőri legénységgel — karhatalmi zászlóaljakat is létrehoztak.

A karhatalom felfogása és alkalmazhatósága egészen más szellemiséggel telítődött a magyar pártállam időszakában. A karhatalom tevékenységből szervezetté is vált. Először az ÁVH keretében állítottak fel országos hatáskörrel karhatalmi szervezetet. A puha diktatúra kiépülésével is fennmaradt a karhatalom önálló országos testületként, melyet 1972-ben oszlattak fel. A karhatalom önálló szervezetként való müködtetése a rendszerváltás időszakában került ismét előtérbe, ekkor azonban már nem önálló országos szervezetként, hanem a magyar rendőrség e célra szervezett szervezeti egységének a felfejlesztése által, azonban továbbra is a rendőrség részeként. A változatos átkereszteléseket megélt rendőri szervezet a köztudatban „készenléti rendőrezred” elnevezéssel változatlanul a Kerepesi úti elhelyezéssel müködik. E rendőri alakulatnak — számos és változatos más feladatai mellett - az alapvető feladata az egész ország területére kiterjedően a csapaterős karhatalmi teendők ellátása, mivel a rendszerváltás során a magyar haderőt e tevékenységből kizárták.

A karhatalom tekintetében annak a politikai csoportosulásnak az akarata érvényesült a rendszerváltáskor, amely nem kívánt visszatérni a magyar hagyományokhoz, hanem szükségesnek tartotta a karhatalmi feladatkör ellátására szakosodott speciális alakulat müködését országos hatáskörrel. Ezzel nyilvánvalóan a magyar rendörség képessége gyarapodott, bár nem egyértelmű hogy a csapaterős karhatalmi tevékenység több tárca közötti felosztottságának a visszaállítása nem lett volna é racionálisabb megoldás. A polgári magyar állam gyakorlatától eltérő sajátos alternatíva ugyanis lényegében a pártállami diktatúra gyakorlatát vette át, természetesen „külföldi mintákra”, „szakszerüségre” és egyéb álcázó jellegü indokokra hivatkozva.

A magyar karhatalom elméleti és szervezeti fejlődését a továbbiakban nyilvánvalóan a magyar állam fejlődésének az iránya fogja megszabni. Ennek megfelelően fog alakulni a magyar rendvédelmi modell, illetve a véderő helye és szerepe is. Ezek függvényében változhatnak a magyar karhatalom szervezeti és müködési szabályozásai. A változások valószínüsíthetőek, hiszen a globalizációval, a nemzetállamok elleni fellépésekkel olyan korábban nem tapasztalt - helyzetek jönnek létre, amelyekre az államoknak a honvédelmi és rendvédelmi képességei alakítása által választ kell adniuk. Nyilvánvalóan egymásra kell 
találniuk a magyar hagyományoknak és a nemzetközi tapasztalatoknak. Valószínüleg nem engedheti meg magának a magyar állam azt, hogy a magyar hagyományokat nélkülöző gyakorlat hátrányainak a terhét viselje. Az ilyen megoldás ugyanis bizonyára kiválóan illeszthető a divatos elvek némelyikéhez, azonban bizton állítható, hogy nem kedvez a nemzeti érdekeinknek.

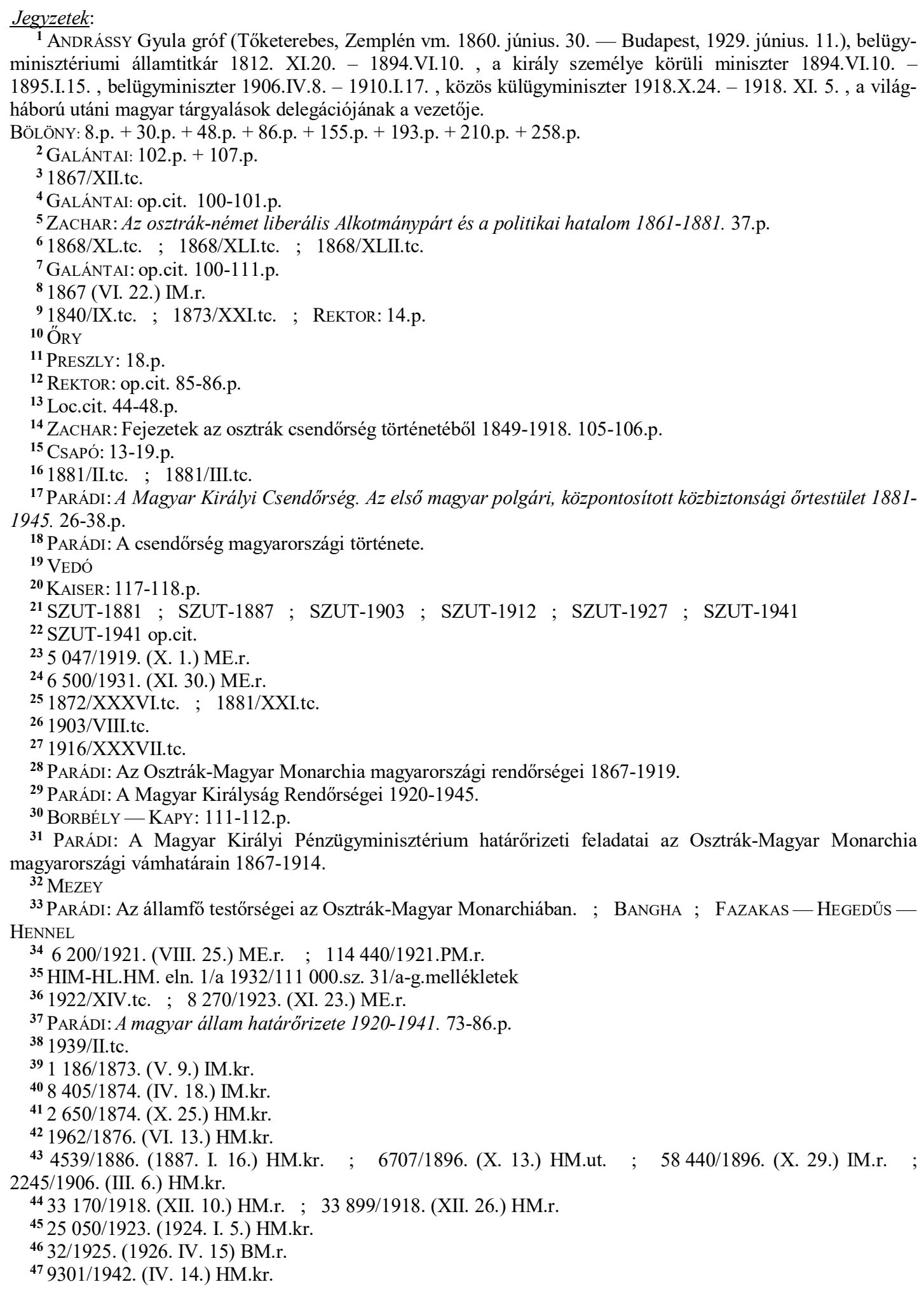




\section{Jegyzetekben alkalmazott röviditések:}

\section{MONOGRÁFIÁK, KISMONOGRÁFIÁK ÉS HASONLÓ JELLEGÜ KÖTETEK}

BANGHA

(33.;)

BORBÉLY - KAPY

(30.;)

CSAPÓ

$(15 . ;)$

FAZAKAS - HEGEdÜS - HENNEL (33.;)

GALÁNTAI

(2.;4.;7.;)

KAISER

MEZEY

PARÁDI: A Magyar Királyi Csendörség. Az elsö magyar polgári, központositott közbiztonsági örtestület 1881-1945.

PRESZLY

(11.;)

REKTOR

(9.;12.;13.;)

ZACHAR

(5.;)

\section{TANULMÁNYOK}

ÖRY

$(10 ;)$
- Bangha Ernő: A Magyar Királyi Testőrség 1920-1944. Budapest, 1990, Európa. 407 p. HU-ISBN 9630752158.

- BorbÉLy Zoltán - KAPY Rezső (szerk.): A 60 éves magyar rendőrség 1881-1941. Budapest, 1942, Halász Irodalmi és Könyvkiadó Vállalat. $594 \mathrm{p}$.

- Csapó Csaba: A Magyar Királyi Csendörség története 1881-1914. Pécs, 1999, Pro Pannónia Kiadói Alapítvány. 186 p. HU-ISBN 96390 7940 5. /Pannónia Könyvek./ HU-ISSN 0237-4277.

FAZAKAS László - Hegedűs Ernő - HenNel Sándor: A Szent Korona örzése. A koronaörök, a koronaörség. Budapest, 2002, Heraldika. 286 p. HU-ISBN 9639204021.

- Galántai József: A Habsburg-monarchia alkonya. Osztrák-magyar dualizmus 1867-1918. Budapest, 1985, Kossuth. 387 p. HU-ISBN 963 0925893.

- KaISer Ferenc: A Magyar Királyi Csendörség története a két világháború között. Pécs, 2002, Pro Pannónia Kiadó Alapítvány. 175 p. HU-ISBN 963907982 0. /Pannónia Könyvek/ HU-ISSN 0237-4277.

- Mezey Barna: A magyar polgári börtönügy kezdetei. Budapest, 1995, Osiris. 230 p. HU-ISBN 963838488 3. /Jogtörténeti Értekezések./ HUISSN 0134-0026.

- PARÁdi József: A Magyar Királyi Csendörség. Az első magyar polgári, központositott közbiztonsági örtestület 1881-1945. Budapest, 2012, Szemere Bertalan Magyar Rendvédelem-történeti Tudományos Társaság. 281 p. HU-ISBN 978963084794 0. /A magyar rendvédelem-történet öröksége, 2./ HU-ISSN 2062-8447.

- PresZly Lóránd: A Magyar Királyi Csendörség története 1881-1919. Budapest, 1920, Honvédelmi Sajtóvállalat. 142 p.

- ReKTOR Béla: A Magyar Királyi Csendörség oknyomozó története. Cleveland, Ohio, USA, 1980, Árpád Könyvkiadó Vállalat. 552 p. USAISBN 0934214018.

- ZACHAR József: Az osztrák-német liberális Alkotmánypárt és a politikai hatalom 1861-1881. Budapest, 1981, Akadémia Kiadó. 349 p. HU-ISBN 963052614 X.

- ŐRY Károly: A Maréchaussée-tól a Gendarmerie Nationale-ig. A Francia Csendörség történeti elözményei. Rendvédelem-történeti Füzetek (Acta Historiae Praesidii Ordinis), VII.évf. (1997) 8.sz. 75-77.p. HU-ISSN 1216-6774. A tanulmány korábbi változata 1996. október 29én Budapesten hangzott el a Szemere Bertalan Magyar Rendvédelemtörténeti Tudományos Társaság által szervezett rendvédelem-történeti tudományos konferenciasorozatnak „A napóleoni közbiztonsági örtestület útja Párizstól - Itálián és Ausztrián keresztül - Budapestig" címü VIII. konferenciáján. A publikált tanulmány az előadás javított, bővített és átdolgozott változata.

PARÁDI: A Magyar Királyi Pénzügyminisztérium határörizeti feladatai az Osztrák-Magyar Monarchia magyarországi vámhatárain 1867-1914.

(31.;)
PARÁDI József: A Magyar Királyi Pénzügyminisztérium határőrizeti feladatai az Osztrák-Magyar Monarchia magyarországi vámhatárain 1867-1914. Hadtörténelmi Közlemények, CIV.évf. (1989) 2.sz. 177196.p. HU-ISSN 0017-6540. 
PARÁDI József: Az Osztrák-Ma- gyar Monarchia magyarországi rendőrségei 1867-1919.

(28.;)

PARÁdi: A Magyar Királyság Rendőrségei 1920-1945.

(29.;)

PARÁDI: A csendőrség magyarországi története.

(18.;)
PARÁDI József: Az Osztrák-Magyar Monarchia magyarországi rendörségei 1867-1919. Rendvédelem-történeti Füzetek (Acta Historiae Praesidii Ordinis), XI. évf. (2005) 13.sz. 97-104.p. HU-ISSN 12166774. A tanulmány korábbi változata 2000. március 19.-én, Párizsban hangzott el a Szemere Bertalan Magyar Rendvédelem-történeti Tudományos Társaság által szervezett rendvédelem-történeti tudományos konferenciasorozatnak „A közbiztonság közös európai örökségünk” címü XIII. konferenciáján. A publikált tanulmány az előadás javított bővített és átdolgozott változata.

PARÁDI József: A Magyar Királyság Rendőrségei 1920-1945. Rendvédelem-történeti Füzetek (Acta Historiae Praesidii Ordinis), XI. évf. (2005) 13.sz. 105-113.p. HU-ISSN 1216-6774.

PARÁDI József: A csendőrség magyarországi története. Rendvédelemtörténeti Füzetek (Acta Historiae Praesidii Ordinis), XVI.évf. (2009) 19.sz. 64-88.p. HU-ISSN 1216-6774. A tanulmány korábbi változata 2005. október 07.-én, Budapesten hangzott el a Szemere Bertalan Magyar Rendvédelem-történeti Tudományos Társaság által szervezett rendvédelem-történeti tudományos konferenciasorozatnak „Másfél évtized nemzeti rendvédelem-történetünk kutatásának szolgálatában” címü XIX. konferenciáján. A publikált tanulmány az előadás javított, bővített és átdolgozott változata.

PARÁDI: Az államfö testörségei az Osztrák-Magyar Monarchiában. (33.;)

PARÁDI József: Az államfö testőrségei az Osztrák-Magyar Monarchiában. Rendvédelem-történeti Füzetek (Acta Historiae Preasidii Ordinis), XXIII. évf. (2013) 27-28-29-30.sz. 155-160.p. HU-ISSN 12166774.

VEDÓ

- Vedó Attila: A Magyar Királyi Csendőrség karhatalmi tevékenységének szabályozása a dualizmus idején. Rendvédelem-történeti Füzetek (Acta Historiae Praesidii Ordinis), XXIII.évf. (2013) 31-32-3334.sz. 170-184.p. HU-ISSN 1216-6774.

ZACHAR: Fejezetek az osztrák csen- dőrség történetéböl 1849-1918.

(14.;)

ZACHAR József: Fejezetek az osztrák csendőrség történetéből 18491918. Rendvédelem-történeti Füzetek (Acta Historiae Praesidii Ordinis), VII.évf. (1997) 8. sz. 105-109. p. HU-ISSN 1216-6774. A tanulmány korábbi változata 1996. október 29.-én Budapesten hangzott el a Szemere Bertalan Magyar Rendvédelem-történeti Tudományos Társaság által szervezett rendvédelem-történeti tudományos konferencia-sorozatnak „A napóleoni közbiztonsági örtestület útja Párizstól - Itálián és Ausztrián keresztül - Budapestig."címü VIII. konferenciáján. A publikált tanulmány az előadás javított, bővített és átdolgozott változata.

\section{BIOGRÁFIÁK}

BÖLÖNY

$(1 . ;)$

BÖLÖNY József: Magyarország kormányai 1848-1975. Budapest, 1978, Akadémia. 328 p. HU-ISBN 963051242 v. /A Magyar Országos Levéltár Kiadványai, IV. - Levéltártan és történeti forrásdokumentumok, 2./ HU-ISSN 0441-4985.

\section{KÉZIRATOK}

PARÁDI: A magyar állam határ- örizete 1920-1941.

(37.;)

PARÁDI József: A magyar állam határörizete 1920-1941. Kandidátusi értekezés (MTA). Kézirat. Budapest, 1990. 264 p. +562 p. melléklet.

\section{LEVÉL- IRAT ÉS DOKUMENTUMTÁRAK}

HIM-HL.HM

Hadtörténeti Intézet és Múzeum Hadtörténeti Levéltár Honvédelmi Minisztériumi iratok convulutuma. 


\section{SZABÁLYZATOK}

SZUT-1881

(21.;)

SZUT-1887

(21.;)

SZUT-1903

(21.;)

SZUT-1912

(21.;)

SZUT-1927

(21.;)

SZUT-1941

(21.;22.;)

\section{JOGSZABÁLYOK}

1840/IX.tc.

(9.;)

1867/XII.tc.

(3.;)

1868/XL.tc.

(6.;)

1868/XLI.tc.

(6.;)

1868/XLII.tc.

(6.;)

1872/XXXVI.tc.

1873/XXI.tc.

(9.;)

1881/II.tc.

(16.;)

1881/III.tc.

(16.;)

1881/XXI.tc.

1903/VIII.tc.

1916/XXXVII.tc

(27.;)

1922/XIV.tc.

(36.;)

1939/II.tc.

(38.;)
- Utasitás a Magyar Királyi Csendörség számára. Budapest, 1881, Pesti Könyvnyomda. 191 p.

- Szervezeti és szolgálati utasitás a Magyar Királyi Csendőrség számára. Budapest, 1887, Központi Községi Nyomda. 224 p. (Az 1887. évi kiadás utánnyomása megjelent 1888-ban és 1898-ban a Pesti Könyvnyomda kiadásában. „,Szabályzat II. szolgálati utasitás. Általános rész.” Címü fejezeteit átírták, melyet kiegészítésként a meglévő kiadványhoz 1900-ban a Pesti Könyvnyomda adott ki 111-155 oldal terjedelemmel, így a „Szervezeti és szolgálati utasitás a Magyar Királyi Csendörség számára" címủ szolgálati könyv terjedelme 361 oldalra nőtt.)

— Utasitások a Magyar Királyi Csendőrség számára. Budapest, 1903, s.n. 78 p.

- Utasítások a Magyar Királyi Csendőrség számára. Budapest, 1912, Várnay és Fia Municipia Kiadó Hivatal. 384 p.

- Szervezeti és szolgálati utasitás a Magyar Királyi Csendőrség számára. Budapest, 1927, Pallas. 387 p.

- Szervezeti és szolgálati utasitás a Magyar Királyi Csendörség számára. Budapest, 1941, Stádium Sajtóvállalat. 411 p.

- 1840/IX.tc. a mezei rendőrségről.

— 1867/XII.tc. a Magyar Korona országai és az Ö Felsége uralkodása alatt álló többi országok között fennforgó közös érdekü viszonyokról, s ezek elintézésének módjáról.

- 1868/XL.tc. a véderőröl.

- 1868/XLI.tc. a honvédségröl.

- 1868/XLII.tc. a népfelkelésről.

— 1872/XXXVI.tc. Budapest fővárosi törvényhatóság alakításáról és rendezéséről.

— 1873/XXI.tc. az 1873. évi államköltségvetésröl.

— 1881/II.tc. a csendőrség legénységi állományának kiegészítéséről.

— 1881/III.tc. a közbiztonsági szolgálat szervezéséről.

— 1881/XXI.tc. a Budapest-fővárosi rendőrségről.

— 1903/VIII.tc. a határrendőrségröl.

— 1916/XXXVII.tc. a Fiumei Magyar Királyi Állami Rendőrségről.

- 1922/XIV.tc. Magyar Királyi Folyamőrség szervezéséről, létszámának, kiegészítési módjának és felfegyverkezésének megállapításáról.

- 1939/II.tc. a honvédelemröl. 
1867 (VI. 22.) IM.r.

(8.;)

1 186/1873. (V. 9.) IM.kr. (39.;)

2 650/1874. (X. 25.) HM.kr. (41.;)

8 405/1874. (IV.18.) IM.kr. (40.;)

1962/1876. (VI. 13.) HM.kr. (42.;)

4 539/1886. (1887. I. 16.) HM.kr. (43.;)

6 707/1896. (X. 13.) HM.ut. (43.;)

58 440/1896. (X. 29.) IM.r. (43.;)

2 245/1906. (III. 6.) HM.kr. (43.;)

33 170/1918. (XII.10.) HM.r. (44.,;)

33 899/1918. (XII.26.) HM.r. (44.;)

5 047/1919. (X. 1.) ME.r.

6 200/1921. (VIII. 25.) ME.r. (34.,)

114 440/1921. (VIII. 25.) PM.r. (34.;)

8 270/1923. (XI. 23.) ME.r. (36;)
1867 (VI. 22.) IM.r. a katonai karhatalomnak végrehajtásoknáli igénybevétele tárgyában.

Magyarországi Törvények és Rendeletek Tára, I.évf. (1867) 1.füzet. 174.p.

- $\quad 1$ 186/1873. (V. 9.) IM.kr. a végrehajtásoknál szükségelt katonai segédlet kirendelése s költségeinek fedezése körüli eljárás tárgyában. Magyarországi Rendeletek Tára, VII.évf. (1873) I.füzet. 182-183.p.

- 2 650/1874. (X. 25.) HM.kr. a karhatalmi, közbiztonsági és közhatósági kirendelések segédlete folytán felmerülő költségek iránt.

Rendeleti Közlöny a Magyar Királyi Honvédség számára, VIII.évf. (1874) 18.sz. 116.p.

- 8 405/1874. (IV.18.) IM.kr. a bírósági végrehajtások alkalmával a karhatalomnak s illetőleg a rendőri segélynek miképpen leendő igénybe vétele tárgyában.

Magyarországi Rendeletek Tára, VIII. évf. (1874) 1. füzet 341-342.p.

- 1962/1876. (VI. 13.) HM.kr. valamennyi a magyar korona területén levő törvényhatósághoz, a katonai karhatalomnak igénybevétele tárgyában.

Magyarországi Rendeletek Tára, X.évf. (1876) I.füzet. 285-289.p.

- 4 539/1886. (1887. I. 16.) HM.kr. a sorhadi, vagy honvédségi karhatalom igénybevétele alkalmával a közhatóságok részéről követendő eljárásról.

Magyarországi Rendeletek Tára, XXI.évf. (1887) I.füzet. 22-29.p.

- 6 707/1896. (X. 13.) HM.ut. a Magyar Korona országaiban a közös hadseregbeli vagy honvéd karhatalomnak igénybevétele alkalmával a közhatóságok részéröl követendő eljárásra nézve.

Rendeleti Közlöny a Magyar Királyi Honvédség számára, XXIII.évf. (1896) 36.sz. 223-233.p.

- 58 440/1896. (X. 29.) IM.r. a karhatalom igénybevétele alkalmával követendö eljárásra nézve kibocsátott új utasítás közlése tárgyában. Igazságügyi Közlöny, V.évf. (1896) 11.sz. 357-366.p.

- 2 245/1906. (III. 6.) HM.kr. A-15 karhatalmi utasítás kiadása tárgyában.

Rendeleti Közlöny a Magyar Királyi Honvédség számára. XXXIII.évf. (1906) 8.sz. 42.p. és melléklet.

- 33 170/1918. (XII.10.) HM.r. a karhatalmak igénylésének, kirendelésének és a kirendelési hatáskörnek szabályozásáról.

Magyarországi Rendeletek Tára, LII.évf. (1918) 1.sz. 2546-2548.p.

- 33 899/1918. (XII.26.) HM.r. a karhatalmak magatartásáról (A hadseregre és a nemzetörségre vonatkozik.). Magyarországi Rendeletek Tára, LII.évf. (1918) 1.sz. 2570-2571.p.

- 5 047/1919. (X. 1.) ME.r. a rendőrség államosításáról. Magyarországi Rendeletek Tára, LIII.évf. (1919) I.füzet. 752-767.p.

- 6 200/1921. (VIII. 25.) ME.r. a vámörség létesítéséröl. Magyarországi Rendeletek Tára, LV.évf. (1922) I.füzet. 223-232.p.

- 114 440/1921. (VIII. 25.) PM.r. a Magyar Királyi Vámőrség létesítéséről szóló 6.200/1921. M. E. számú kormányrendelet végrehajtásáról. Magyarországi Rendeletek Tára, LV.évf. (1922) I.füzet. 1594-1623.p.

- $\quad 8$ 270/1923. (XI. 23.) ME.r. a folyamrendészet gyakorlásáról és a m. kir. folyamőrség szervezéséröl, létszáma kiegészitési módjainak és felfegyverzésének megállapításáról szóló 1922: XIV. t.-c. végrehajtásáról. Magyarországi Rendeletek Tára, LVII.évf. (1923) I.füzet. 335-340.p.

25 050/1923. (1924. I. 5.) HM.kr. — 25 050/1923. (1924. I. 5.) HM.kr. karhatalmi szolgálat ellátása a (45.;) Magyar Királyi Honvédség számára.

Honvédségi Közlöny, LI.évf. (1924) 2.sz. 16.p. + melléklet. 
4 132/1925. (1926. IV. 15) BM.r. (46.;)

6 500/1931. (XI. 30.) ME.r. (24.;)

9 301/1942. (IV. 14.) HM.kr. (47.;)
- 4 132/1925. (1926. IV. 15.) BM.r. a katonai karhatalom igénybevételéről és alkalmazásáról. Magyarországi Rendeletek Tára, LX.évf. (1926) 1.sz 275-285.p.

- 6 500/1931. (XI. 30.) ME.r. a rendőrség szervezeti változásairól. Magyarországi Rendeletek Tára, LXV.évf. (1931) XII.füzet. 15331534.p.

- 9 301/1942. (IV. 14.) HM.kr. A-15 szabályzat a karhatalmi szolgálat ellátására a Magyar Királyi Honvédség számára.

Honvédségi Közlöny, LXIX.évf. (1942) 17.sz. 175.p. + melléklet. 